\section{Commentary: Opening a window when surgeons face awesome responses to immunotherapy}

\author{
Stephan Adamour Soder, MD, and \\ Moishe Liberman, MD, PhD
}

Immunotherapy has profoundly changed the paradigm in the treatment of several solid tumors over the past decade. In metastatic and locally advanced cutaneous squamous cell carcinomas not amenable to curative resection, immune checkpoint inhibition with cemiplimab have shown a $47 \%$ objective response rate. ${ }^{1}$ Another phase 2 open-label study including patients with locally advanced cutaneous squamous cell carcinoma, showed a $44 \%$ objective response rate with cemiplimab using the Response Evaluation Criteria in Solid Tumors version 1.1. ${ }^{2}$

In many patients, the significant local response to immunotherapy and associated tumor shrinkage/contraction may change surgical planning. Some tumors considered nonamenable to curative resection, by the predicted impossibility of achieving a complete resection, patient-related clinical conditions, or the aggressiveness of the resection, have shown an impressive reduction after immunotherapy leading to a reconsideration of aggressive surgical excision.

We enthusiastically enjoyed the report by Choi and colleagues, ${ }^{3}$ which describes the successful resection of a large cutaneous squamous cell carcinoma with chest wall and thoracic inlet invasion. Notably, after 2 cycles of cemiplimab and 1 cycle of radiotherapy, the tumor underwent a significant superficial contraction with associated new bone erosion and close contact with the subclavian vessels. The

From the Division of Thoracic Surgery, Department of Surgery, University of Montréal, Montréal, Québec, Canada.

Disclosures: The authors reported no conflicts of interest.

The Journal policy requires editors and reviewers to disclose conflicts of interest and to decline handling or reviewing manuscripts for which they may have a conflict of interest. The editors and reviewers of this article have no conflicts of interest.

Received for publication Aug 29, 2020; revisions received Aug 29, 2020; accepted for publication Sept 4, 2020; available ahead of print Sept 15, 2020.

Address for reprints: Moishe Liberman, MD, PhD, Division of Thoracic Surgery, Department of Surgery, Centre Hospitalier de l'Université de Montréal, Centre de Recherche du CHUM, Room R04.402-1, 900 Rue Saint-Denis, Montréal, QC H2X 0A9 Canada (E-mail: moishe.liberman@umontreal.ca).

JTCVS Techniques 2020;4:332-3

2666-2507

Copyright (c) 2020 The Authors. Published by Elsevier Inc. on behalf of The American Association for Thoracic Surgery. This is an open access article under the CC BY-NCND license (http://creativecommons.org/licenses/by-nc-nd/4.0/).

https://doi.org/10.1016/j.xjtc.2020.09.003

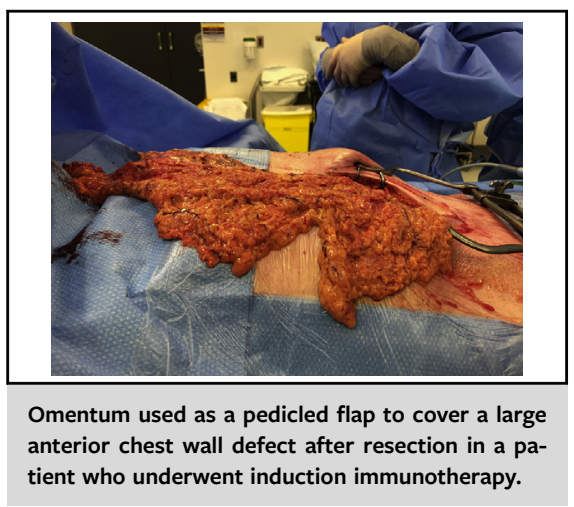

CENTRAL MESSAGE

Varying tumor response patterns

to immune checkpoint inhibitors

have been observed. Some pa-

tients will benefit from aggres-

sive, well-planned surgical

excision and reconstruction.

decision for aggressive resection was justified to prevent potential catastrophic bleeding.

Image-based tumor burden evaluation in patients receiving immunotherapy is sometimes challenging because the tumors can exhibit many patterns of response after delivery of treatment. Pseudoprogression and dissociated responses have been observed in many solid tumors after immunotherapy and are associated with better survival than true progression. However, tumor growth or the development of new lesions can be observed in these scenarios. Especially in cases of dissociated responses, a window for surgical treatment may open and must not be neglected. The decision to continue delivery of a drug versus proceed with aggressive surgical excision must be taken individually with consideration of the clinical features and the possibility of achieving complete resection. Biomarkers such as circulating tumor $\mathrm{DNA}^{4}$ and chromosomal instability quantification of cell-free DNA ${ }^{5}$ are showing encouraging accuracy in evaluating response to immunotherapy and might be another useful tool in surgical decision making in the near future.

In the case presented by Choi and colleagues ${ }^{3}$ the decision to proceed with resection of such a large tumor was accompanied by the need to reconstruct the chest wall. Acellular collagen matrix patches combine rigidity and durability needed for chest stabilization, along with easy handling and strength for suture fixation. It also allows a remodeling process with tissue integration and neovascularization, which may reduce infection risk 
and help with healing. ${ }^{6}$ Because the chest wall offers significant stretch, the collagen matrix's tissue origin must be considered when selecting the prosthesis, due to the fact that the porcine origin matrix apparently offers more stretch resistance than those from humans. Prosthetic patches must always be covered with well-vascularized tissue flaps, preferentially muscle or omentum. We congratulate the authors for the surgical and oncological success in this complex case.

\section{References}

1. Migden MR, Rischin D, Schmults CD, Guminski A, Hauschild A, Lewis KD, et al. PD-1 blockade with cemiplimab in advanced cutaneous squamous-cell carcinoma. N Engl J Med. 2018;379:341-51.
2. Migden MR, Khushalani NI, Chang ALS, Lewis KD, Schmults CD, HernandezAya L, et al. Cemiplimab in locally advanced cutaneous squamous cell carcinoma: results from an open-label, phase 2, single-arm trial. Lancet Oncol. 2020;21: 294-305.

3. Choi JJ, Allen RJ, Bains MS, Cohen MA, Yu Y, Elmadhun N, et al. Complex chest wall surgery to prevent vascular complications after immunotherapy and radiation treatment. J Thorac Cardiovasc Surg Tech. 2020;4:329-31.

4. Cabel L, Proudhon C, Romano E, Girard N, Lantz O, Stern MH, et al. Clinical potential of circulating tumour DNA in patients receiving anticancer immunotherapy. Nat Rev Clin Oncol. 2018;15:639-50.

5. Weiss GJ, Beck J, Braun DP, Bornemann-Kolatzki K, Barilla H, Cubello R, et al Tumor cell-free DNA copy number instability predicts therapeutic response to immunotherapy. Clin Cancer Res. 2017;23:5074-81.

6. Schmidt J, Redwan B, Koesek V, Heitplatz B, Bedetti B, Aebert H, et al. Thoracic wall reconstruction with acellular porcine dermal collagen matrix. J Thorac Cardiovasc Surg. 2016;64:245-51. 